\title{
OVERSOWING WHITE CLOVER INTO CLEARED AND UNIMPROVED NORTH ISLAND HILL COUNTRY - THE ROLE OF MANAGEMENT, FERTILISER, INOCULATION, PELLETING AND RESIDENT RHIZOBIA.
}

\author{
M.J. MACFARLANE and P.M. BONISH \\ Whatawhata Hill Country Research Station, \\ M.A.F., Hamilton. \\ 'Ruakura Agricultural Research Centre, \\ M.A.F., Hamilton.
}

\section{Abstract}

The roles of inoculation, pelleting and fertiliser were examined when white clover was oversown into recently cleared North Island hill country with a low resident white clover rhizobia population. Inoculation aided establishment at some sites. Recovery of inoculant strain from plants and soil was generally low, initial nodulation by the inoculant strain being replaced by expanding resident rhizobial populations. Pelleting was necessary to ensure inoculant survival on seed and inoculant establishment. Fertiliser application at oversowing consistently increased seedling and later plant size.

Grazing managements (pre-and post-oversowing), treading and chemical sward suppression effects were assessed on paddock scale oversowings of white clover into unimproved hill pastures. Pre-oversowing grazing to $900 \mathrm{~kg} \mathrm{DM} / \mathrm{ha}$ or less, and frequent post-oversowing grazings, were necessary to control competition from the resident sward. The use of paraquat: diquat at a low rate was required to maximise establishment. Reducing the water rate with herbicide from 200 to 60 litres/ha maintained high establishment on steep slopes and attained $80 \%$ of potential on easy slopes. Additional treading was a practical method of increasing establishment.

Keywords: White clover, Trifolium repens, oversowing, establishment, rhizobia, competition, fertiliser, inoculation, pelleting, paraquat, diquat, treading, hill country.

\section{INTRODUCTION}

The roles of inoculation, pelleting and resident rhizobia in the establishment of oversown white clover (Trifolium repens) in South Island hill and high country are well known (Lowther and McDonald 1973, Lowther 1976). The effects of these factors on white clover establishment in North Island hill country are less well defined. Studies have shown the presence of an extensive but small resident white clover rhizobial population in land not in pasture in the North Island (Bonish unpublished, Hale 1980). Even with a background resident rhizobial population, oversowing failures due to nodulation problems have been reported (Goold 1968). Bonish and Steele (1985) reported on nodulation failures in North Island soils that were once pasture and had been continuously cropped for many years.

The efficient use of fertiliser, subdivision and stock in establishing oversown species into existing swards in hill country has been long known (Suckling 1954). Percentage of seeds sown that ultimately establish and survive are often very low (Charlton 1977). Treading of pastures and oversown seed and the use of herbicides for resident sward suppression, as aids to establishment, during oversowing into existing swards has long been advocated (Suckling 1949, Blackmore 1961). It has not been demonstrated by comparative studies that there are benefits when these treatments are applied to paddock scale oversowings in steep hill country.

With the increase of newly released pasture cultivars, there has been an increased need for understanding the factors affecting successful establishment of oversown seed into unimproved hill country pastures. 
An earlier evaluation at Whatawhata Hill Country Research Station, highlighted the roles of sward control and treading to ensure establishment of a range of seeds oversown into easy hill country (Sithamparanathan unpublished). A low rate of paraquat ( $250 \mathrm{~g}$ ai/ha) was capable of acting as a suppressant to check resident sward growth for a period following over-sowing. Establishment increased linearly with treading intensity at sowing, however maximum establishment was achieved with treading intensities that could not be realised in hill farming practice.

The herbicide rates used contrasted with much of previously reported work, where the emphasis has been on the complete or near complete removal of resident grasses (Blackmore 1961, 1964a,b). The establishment of seed oversown into unimproved steep hill country using low rates of herbicide to suppress, rather than remove the existing sward has seldom been assessed. Also lowering the amount of water per hectare used to apply a herbicide may have a significant effect upon the cost of development, if the use of a herbicide is warranted.

This paper summarises results from two series of trials designed to produce guidelines for the introduction of white clover into North Island hill country. The first series investigated the roles of inoculation, pelleting, resident rhizobia and fertiliser on the establishment of white clover oversown into recently cleared bush and scrub lands. The second examined the effects of pre- and post-oversowing grazing management, treading and resident sward suppression using herbicides, on the establishment of white clover oversown into existing unimproved hill country pastures.

\section{METHODS}

\section{Cleared land}

Trial sites were chosen on two contrasting soil parent materials (Dunmore yellow brown loam derived from volcanic ash, $\mathrm{pH} 5.7$, Olsen $\mathrm{P} 2 \mathrm{ppm}$, ex recent root raking, located at Waitetuna, Raglan County and a yellow brown earth hill soil derived from sedimentary mudstone, $\mathrm{pH} 5.2$, Olsen $\mathrm{P} 7 \mathrm{ppm}$, ex recent burn, located at Huntly). Separate trials were conducted on north and south facing slopes (20-25 degrees) for spring and autumn oversowings. Seed and fertiliser treatments were applied to $1.5 \mathrm{x}$ $1.5 \mathrm{~m}$ plots in each of 5 blocks. Grasslands Huia white clover was sown throughout with four pelleting and inoculation treatments:

1. uninoculated bare seed;

2. slurry inoculated bare seed;

3. uninoculated pelleted seed;

4. inoculated and pelleted seed.

Inoculant loading at sowing ranged between $710-2,200,000$ rhizobia/seed for slurry inoculated and 2,260.19,300 rhizobia/seed for pelleted, inoculated seed.

Fertiliser was applied at:

1. nil;

2. $200 \mathrm{~kg} / \mathrm{ha}$ molybdic superphosphate;

3. $600 \mathrm{~kg} / \mathrm{ha}$ molybdic superphosphate.

Fertiliser treatments were chosen to represent both maintenance and capital fertiliser applications.

Seedling establishment, vigour and survivals were determined for 4 months after oversowing. Most probable numbers (MPN) of soil rhizobia were estimated pre- and post-oversowing (Date and Vincent 1962). The success of inoculant establishment in nodules and soil was assessed by an indirect fluorescent antibody method (Goldman 1968). The effectiveness of resident rhizobia was assessed relative to the strain PDDCC 2666, effective on white clover, using seedlings grown aseptically on agar slopes (Vincent 1970). 


\section{Unimproved pasture}

Two trials were carried out at Whatawhata Hill Country Research Station during 1983 and 1984. Two replicate paddocks, each 3.6 ha of predominantly north facing aspect (65\% of each area being greater than 30" slope), were each divided into three main-plots. Spray treatments were randomly allocated within main-plots:

1. nil spray;

2. paraquat $200 \mathrm{~g}$ ai in 60 litres water/ha (1983) or paraquat:diquat $6: 1200 \mathrm{~g}$ ai/ha in 60 litres water/ha (1984);

3. paraquat $200 \mathrm{~g}$ ai/ha in 200 litres/ha (1983) or paraquat:diquat $6: 1200 \mathrm{~g}$ ai/ha in 200 litres water/ha (1984).

Sub-plots, 2 x lm, were selected on easy (15-25" slope) and steep (32.35" slope) within main-plots. Sub-plot selection was based upon aspect, slope and resident vegetation. Management treatments within sub-plots were imposed by caging plots as paddock scale treatments progressed. Management treatments were:

1. existing - oversowing into existing vegetation $(2200 \mathrm{~kg} \mathrm{DM} / \mathrm{ha}$ easy, $1700 \mathrm{~kg}$ DM/ha steep);

2. graze only - oversowing into $1200 \mathrm{~kg} \mathrm{DM} / \mathrm{ha}$, with no stock treading;

3. graze + tread - oversowing at $1200 \mathrm{~kg} \mathrm{DM} / \mathrm{ha}$ with further treading and grazing for two days;

4. graze + tread + shepherding — same as 3, plus sheep were mobbed together and shepherded (walked) once through plot areas.

Prior to trial commencement in late May, existing vegetation consisted of late summer pasture surpluses, characterised by a large population of dead matter, predominantly seedhead. On easy slope the resident vegetation was white clover, new seedlings of subterranean clover (T. subterraneum), browntop (Agrostis capillaris), perennial ryegrass (Lolium perenne), ratstail (Sporobolus africanus) and paspalum (Paspalum dilatatum) with little bare ground present. The steep slope contained mainly browntop, sweet vernal (Anthoxanthum odoratum), rice grass (Microlaena stipoides), danthonia (Rytidosperma $s p$ ) and ratstail, with sparse white clover and many annual legume seedlings, (subterranean clover, suckling clover ( $T$. dubium), lotus (Lotus subbiflorus) and 10\% bare ground.

In mid May of each year each replicate was grazed with 200 sheep/ha for 5 days. During this time residual dry matter was reduced to $1200 \mathrm{~kg} \mathrm{DM} / \mathrm{ha}$ on easy slope and $900 \mathrm{~kg} \mathrm{DM} /$ ha on steep slope. Sub-plots were then oversown with $4 \mathrm{~kg} / \mathrm{ha}$ of 'Grasslands Huia' white clover (1983) and 'Feather marked' white clover C4851 (Corkill 1963) (1984) and with $250 \mathrm{~kg} 30 \%$ potassic molybdic superphoshate/ha. Grazing was allowed to continue for a further 2 days before sheep were removed. At stock removal paddock residuals were $500 \mathrm{~kg} \mathrm{DM} / \mathrm{ha}$ on easy slope and $700 \mathrm{~kg} \mathrm{DM} / \mathrm{ha}$ on steep slope. Main-plot spray treatments were then applied by helicopter.

Post oversowing grazing management allowed pasture to accumulate to approximately $1200 \mathrm{~kg} \mathrm{DM} / \mathrm{ha}$ before beinggrazed to $700-800 \mathrm{~kg}$ DM/ha. To assess effects of potential post-oversowing mismanagement, half of each plot in the control spray treatment were caged to exclude grazing every second post-oversowing grazing (alternate graze).

Seedling establishment and stolon growing point densities were assessed at intervals after oversowing.

\section{RESULTS AND DISCUSSION}

\section{Cleared land}

Resident white clover rhizobial populations were extremely variable within sites, ranging from 40 to $58,000 / \mathrm{g}$ soil on north slopes and 47 to $4,140 / \mathrm{g}$ soil on south slopes. All sites contained high proportions of rhizobia which were totally ineffective and/or 
much less effective in nitrogen fixation than the inoculating strain (PDDCC 2666). For example Figure 1 shows the distribution in the range of effectiveness of nitrogen fixing ability of rhizobia within the rhizobial populations at three trial sites. Because of the magnitude of these differences it would be expected that just the introduction of the more effective inoculant strain, at oversowing, would benefit establishing seedlings. Seedling vigour should be greater if nodulated by the introduced strain rather than resident rhizobia.

Effectiveness $(\mathrm{P}<0.05)$

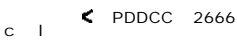

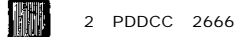

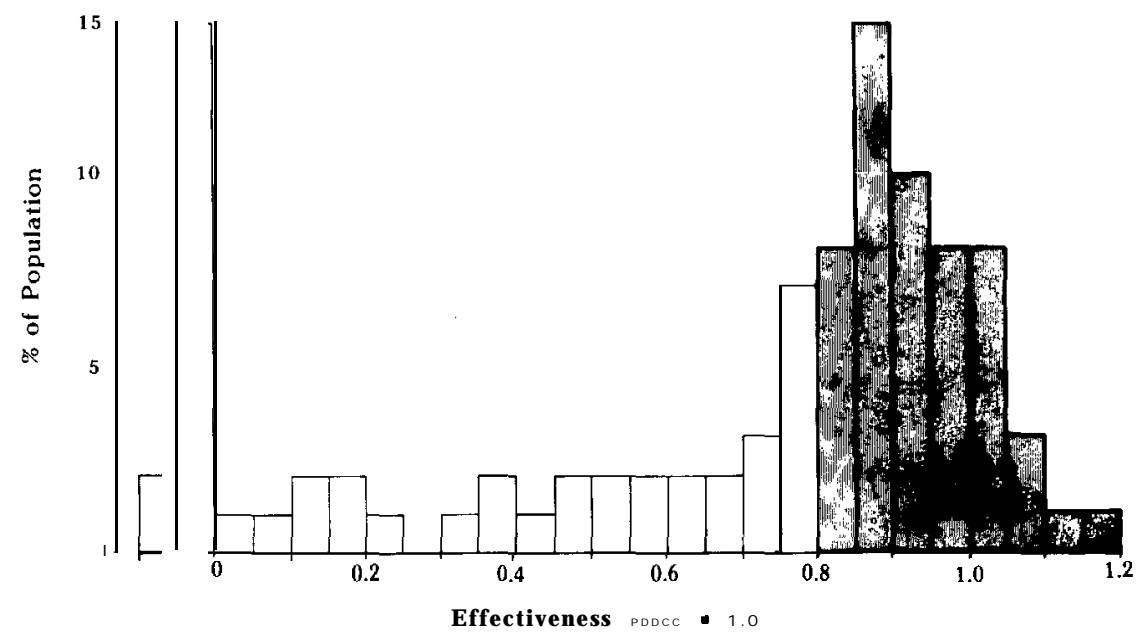

FIGURE 1: Range of effectiveness of resident rhizobia, relative to inoculating strain (PDDCC 2666=1.0), taken from effectively nodulated plants in soil MPN counts from 3 trials, all populations combined - Huntly north spring, $\mathrm{H}$ untly south spring, and Waitetuna south spring oversowings.

TABLE 1: Numbers of significant $(\mathbf{P}<\mathbf{0 . 1})$ positive (+ve), negative (-ve) and non significant (ns) effects observed over 7 oversowing trials into recently cleared hill country.

\begin{tabular}{|c|c|c|c|c|c|c|c|}
\hline & Initial & & Seedling & Plant & $\begin{array}{l}\text { Inc } \\
\text { Esta }\end{array}$ & ment & $\begin{array}{c}\text { Soil } \\
\text { R hizobia }\end{array}$ \\
\hline & Establish. & Survival & Vigour & Vigour & Plant & Soil & $\mathrm{N}$ umbers \\
\hline Inocula & & & & & & & \\
\hline tve & 1 & 2 & 2 & 1 & 5 & 4 & 2 \\
\hline -ve & 0 & 0 & 0 & 0 & 0 & 0 & 0 \\
\hline ns & 6 & 5 & 5 & 6 & 2 & 3 & 5 \\
\hline Pelletin & & & & & & & \\
\hline tve & 1 & 1 & 3 & 0 & 3 & 2 & 2 \\
\hline$-v e$ & & 0 & 0 & 0 & 1 & 0 & 0 \\
\hline $\mathrm{ns}$ & 5 & 6 & 4 & 1 & 3 & 5 & 5 \\
\hline Fertilis & & & & & & & \\
\hline tue & 2 & 3 & 7 & 6 & 3 & 1 & 1 \\
\hline -ve & 0 & 0 & 0 & 0 & 0 & 0 & 0 \\
\hline ns & 5 & 4 & 0 & 1 & 4 & 6 & 6 \\
\hline
\end{tabular}


Table 1 summarises all positive, negative and non significant $(P<0.1)$ inoculation, pelleting and fertiliser main effects for measurements made at 7 sites. Mean percentage of viable oversown seed establishing 12 to 16 weeks following oversowing, ranged 10 to $45 \%$ across all sites.

Responses in survival and vigour to inoculation indicated that in situations of nil to low resident rhizobia the inoculating strain was necessary to ensure seedling establishment and survival. In these situations the background population was not present in enough numbers to ensure early nodulation of seedlings. In most situations the resident population was adequate for establishment, however, improved seedling and plant vigour were associated with nodulation with the inoculating strain in 2 out of 7 instances.

Pelleting responses were mainly confined to an increased presence of inoculant in nodules and soil samples. This indicates that its major role is to ensure the survival of inoculant on seeds up until sowing and its transfer to the soil. These results are similar to those found in South Island hill and high country situations (Lowther 1976).

There were consistent linear responses to fertiliser in most assessments of plant vigour. Fertiliser responses in seedling and plant weights were often four fold. Establishment and survival were also improved. In some trials inoculant establishment was increased by fertiliser, presumably due to increased host plant vigour recorded at the same sites. These consistent effects have implications for seed/fertiliser distribution. Both seed and adequate fertiliser must be placed together for successful establishment.

Following oversowing the resident rhizobia responded to the presence of white clover seedlings by rapidly multiplying at most sites. Population increases over 6 to 12 weeks ranged 1.3 to 149 times, e.g. Figure 2. Such increases in rhizobial numbers were similar for plots receiving both inoculated and uninoculated treatments.

The large increase in the resident rhizobial population must have contributed to the low recovery of inoculant from plant nodules and soil. Introduced rhizobia appear unable to compete with naturalised strains when introduced into soils already supporting white clover swards (Pankhurst and Greenwood 1983). Even when introduced into soils containing very low numbers of resident rhizobia, the inoculating strain was unable to survive and/or compete against the rapidly increasing resident population. The fate of inoculating rhizobia has been followed when introduced into existing grasslands containing white clover and consequently high populations of white clover rhizobia (Gaur and Lowther 1982). Inoculating strains competed poorly through time, with resident rhizobia continuing to form most nodules. The inoculating strain's fate has not previously been studied from oversowing. When introduced into overall very variable populations, inoculating strain competitiveness was low, further emphasising the low competitive ability of strains in current use. The inability of inoculant rhizobia to compete with resident rhizobiais a common field problem and a major limitation to the value of inoculation (Alexander 1985).

The role of inoculation of seed sown into low populations of resident rhizobia appears to be confined to aiding initial establishment. Once the host plant is introduced, resident rhizobia quickly multiply and take over and dominate the inoculating strain.

\section{Unimproved pasture}

Treatment effects were similar for both 1983 and 1984 trials. An overall establishment of $20 \%$ of oversown seed in 1983, compared to $47 \%$ in 1984, reflected a much cooler winter in 1983 than 1984. There were consistent significant spray and management effects on seedling establishment and stolon growing point densities at all measurements (Table 2).

Easy and steep slopes behaved similarly to management and spraying treatments. In the absence of sward suppression by herbicide, oversowing into existing vegetation 
(Residual $1200 \mathrm{~kg} \mathrm{DM} / \mathrm{ha}$ ), with no vegetation control resulted in establishment of less than one quarter of the potential. Establishment was increased by grazing the existing sward down to $1200 \mathrm{~kg} \mathrm{DM} /$ ha with no treading, while treading and further grazing to $500-700 \mathrm{~kg} \mathrm{DM} /$ ha was able to raise establishment to nearly two thirds the potential for each slope class. On both easy and steep slopes, highest rates of establishment were approached only when pre-oversowing grazing management was coupled with the application of herbicide. This indicates the large role that the resident sward has in controlling potential establishment.

There was an average two fold increase in establishment through the use of paraquat:diquat in 200 litres water/ha over nil spray treatments. Reducing the water rate to 60 litres/ha achieved establishments of near $80 \%$ of potential. A reduction in the applied water rate can reduce application costs \$23-31 ha, which represent approximately $30 \%$ of total oversowing costs on a 10 ha area (Macfarlane 1985).

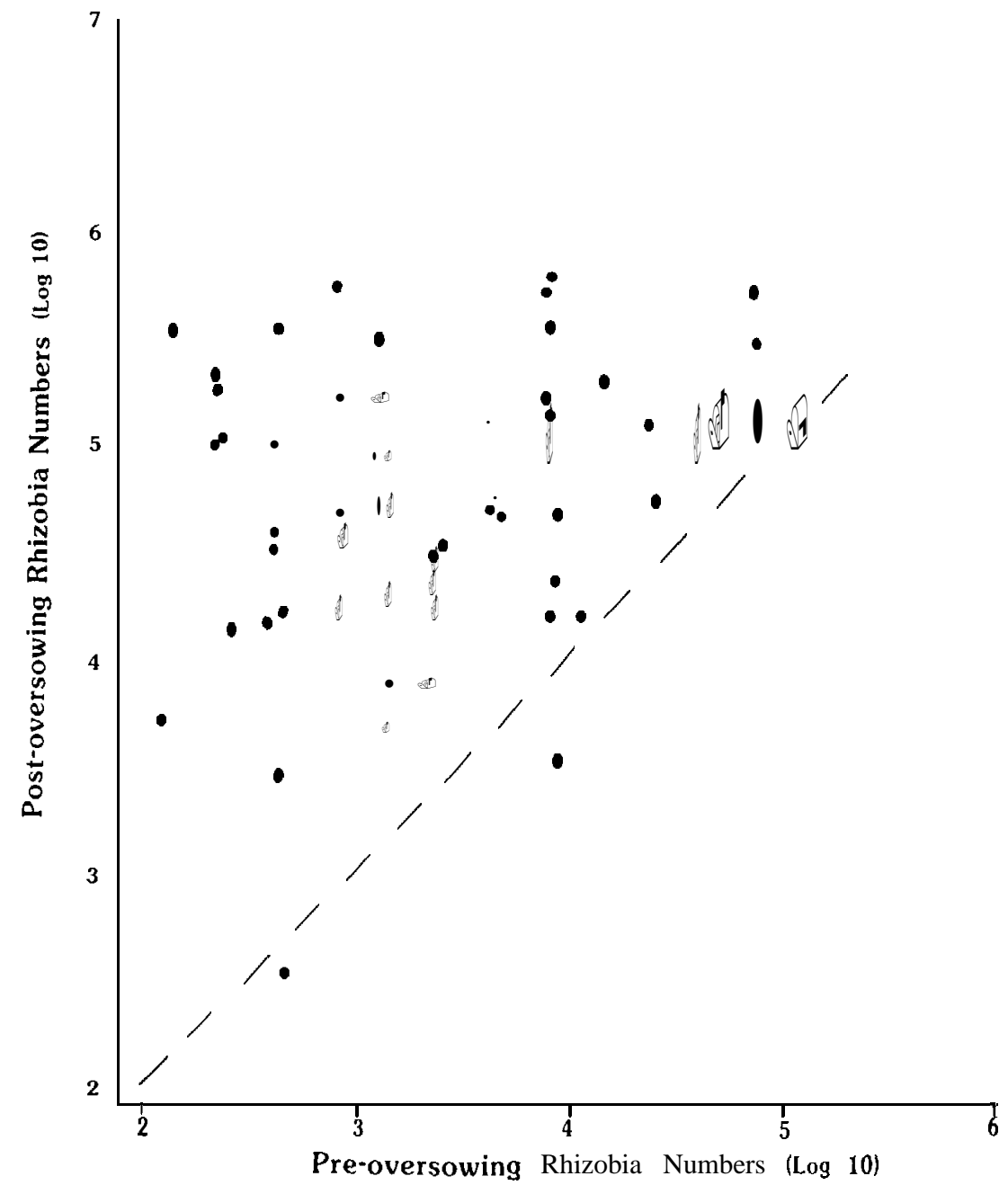

FIGURE 2: Soil rhizobia numbers $(\log 10)$ of uninoculated plots, pre- and post-oversowing from oversowing in Huntly, north aspect, autumn oversowing. 


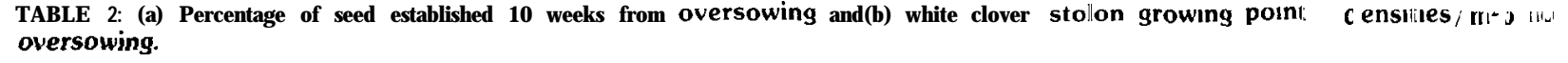

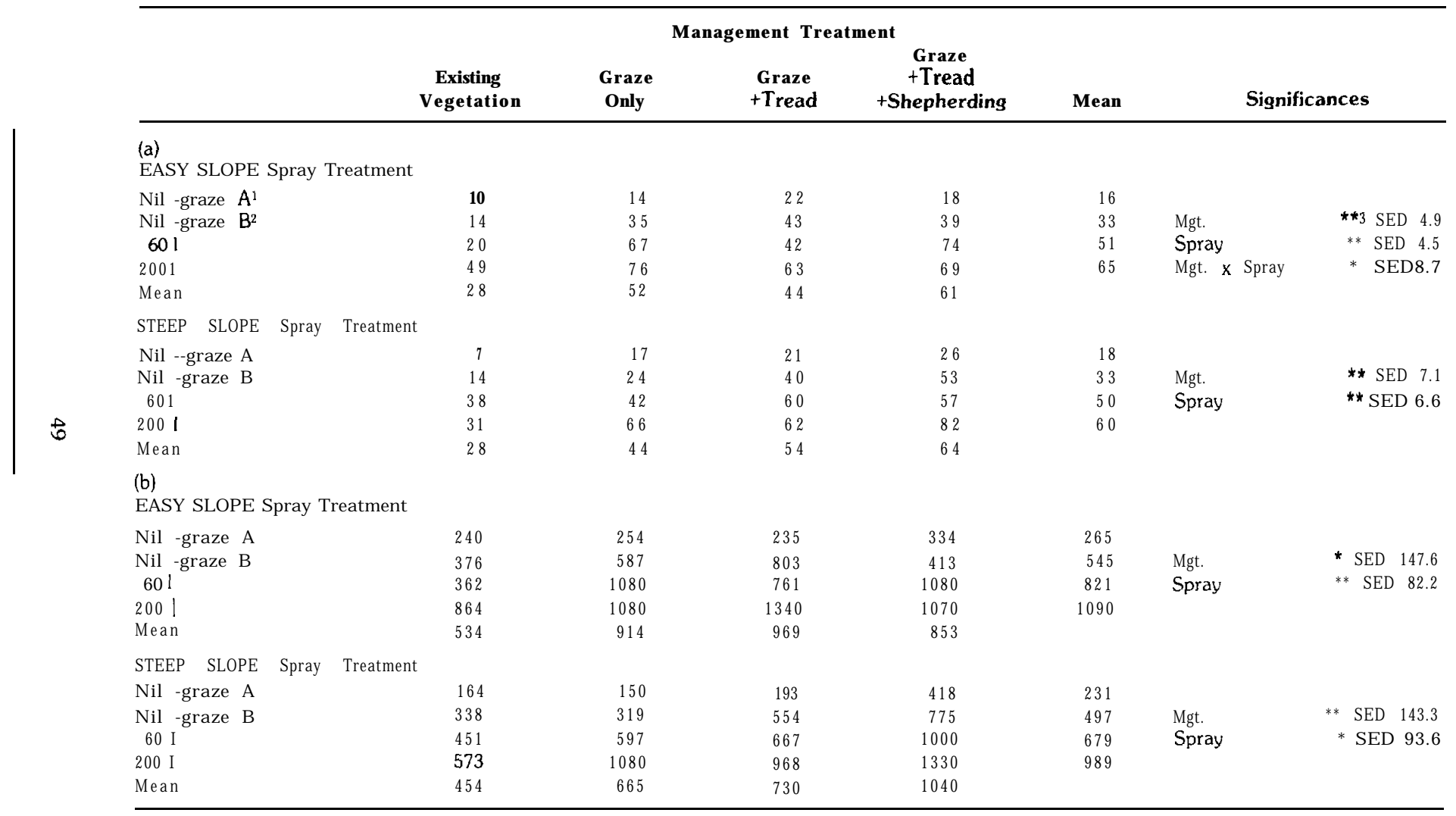

1 Graze $A=$ alternate graze management, see text, data not included in analysis and table means. 2 Graze $B=$ regular grazing management.

$3 *<\mathrm{P} \quad 0.05$ and 0.01 respectively. 
Shepherding stock through plot areas increased the amount of bare ground by $20 \%$, disturbed more soil and vegetation and reduced the amount of seed visible on the surface by $15 \cdot 30 \%$. This increased initial establishment, and by 6 months still provided higher stolon densities on steep slopes.

By only grazing 'alternative' plots every second post-oversowing grazing, establishment was halved. This indicates the continued need for control of the sward to ensure competition is reduced to a minimum. This was achieved by grazing at $1000-1200 \mathrm{~kg} \mathrm{DM} /$ ha to a level of $700-800 \mathrm{~kg} \mathrm{DM} / \mathrm{ha}$. In practice this would require more frequent grazing (twice) of recently oversowing paddocks than all other farm paddocks in a rotation.

These data substantiate the values of treading, sward control and the use of chemical sward suppression, during oversowing into unimproved pastures, as put forward by Suckling (1949), Blackmore (1961, 1964b) and others. It also allows for comparisons, of the likely gains and losses in establishment, of adopting a range of oversowing strategies in steep North Island hill country.

Oversowing into existing swards has inherent difficulties as a dense sward (large number of growing points per $\mathrm{m}^{2}$ ) may already exist. The level of control of growth (competition) achieved, determines the success of white clover seedling establishment. Sward density must be controlled during the early phase of seedling establishment for oversowing to be successful. Grazing pre- and post-oversowing is critical to gain control of sward density. The application of paraquat:diquat $(6: 1)$ assists in controlled density but it is not a substitute for poor or nil grazing management.

\section{PRACTICAL GUIDELINES}

Oversowing into cleared North Island hill country

1. Pelleted and inoculated white clover seed should be used in all introductions where land has not recently supported white clover. There will be instances where there will be little if any benefit. The use of pelleted and inoculated seed is an 'insurance' against low establishment and initial plant vigour.

2. Fertiliser should be applied to the maximum that the development budget will allow

Oversowing into unimproved swards

1. Hard grazing before oversowing is essential.

2. Spraying with a sward suppressant, e.g. paraquat:diquat $(6: 1)$, is necessary to maximise establishment.

3. Reducing the water rate with herbicide may result in 30-50\% saving in development costs with a moderate decrease in potential establishment on easy slopes and no decrease on steep slopes.

4. Shepherding stock across slopes is a practical method of increasing soil disturbance, seed/soil contact and establishment.

5. Post-oversowing grazing management must maintain a low level of competition, graze at $1000-1200 \mathrm{~kg} \mathrm{DM} /$ ha to $700-800 \mathrm{~kg} \mathrm{DM} / \mathrm{ha}$. Such management should be maintained for 12 months.

6. Only do an area that you can manage.

\section{Acknowledgments}

Mintech (NZ) Ltd for pelleting seed lines and supply of inoculants. M.A. Tucker, A.G. McGowan, J. Manson for technical assistance. F.A. Neville for fluorescent antibody tests.

\section{References}

Alexander, M. 1985. Advances in Microbial Ecology 8: 163-183.

Blackmore, L.W. 1961. Proc. N.Z. Weed \& Pest Cont. Conf. 14: 53.58 
Blackmore, L.W. 1964a. N.Z. J. Agr. 108: 122-135.

Blackmore, L.W. 1964b: Ibid 108: 223324.

Bonish, P.M.; Steele, K. W. 1985. Ibid 28: 299.303.

Corkill, L. 1963. N.Z. J. agr. Res. 6: 457-459.

Charlton, J.F.L. 1977. N.Z. J.exp. Agric. 5: 385.390.

Date, R.A.; Vincent, J.M. 1962. Aust. J. exp. agric. anim hus 2: 5.7

Goldman, M. 1968. Fluorescent antibody methods. Academic Press. New York.

Gaur, Y.D.; Lowther, W.L. 1982. N.Z. J. agr. Res. 25: 277.280.

Goold, G.J. 1968. Proc. N.Z. Grass/d. Ass. 29: 8895

Hale, C.N. 1980. Ibid 41:138-145.

Lowther, W.L.; McDonald, IR. 1973. N.Z. J. exp Agric. 1:175.179

Lowther, W.L. 1976. Proc. N.Z. Grassld. Ass. 38: 175-181.

Macfarlane, M.J. 1985. Proc. N.Z. Weed \& Pest Cont. Conf. 38: 110-114

Pankhurst, C.E.; Greenwood, R.M. 1983. N.Z. J. exp. Agric. 11: 165-169

Suckling, F.E.T. 1949. Proc. N.Z. Grassid. Ass. II: 89-117.

Suckling, F.E.T. 1954. NZ J. sci. tech. 36A: 237-273

Vincent, J.M. 1970. "A manual for the practical study of root nodule bacteria". IBP Handbook No. 15 Blackwell Scientific Publications, Oxford. 